Abstracta Iranica Abstracta Iranica

Revue bibliographique pour le domaine irano-aryen

Volume 28 | 2007

Comptes rendus des publications de 2005

\title{
«Un écho aux pratiques cultuelles zoroastriennes en Dt 4-5 ». Trans., 29, 2005, pp. 189-199.
}

\section{Astrid Nunn}

\section{(2) OpenEdition}

1 Journals

\section{Édition électronique}

URL : http://journals.openedition.org/abstractairanica/16442

DOI : 10.4000/abstractairanica.16442

ISSN : 1961-960X

Éditeur :

CNRS (UMR 7528 Mondes iraniens et indiens), Éditions de l'IFRI

Édition imprimée

Date de publication : 15 mai 2007

ISSN : 0240-8910

\section{Référence électronique}

Astrid Nunn, « « Un écho aux pratiques cultuelles zoroastriennes en Dt 4-5 ». Trans., 29, 2005, pp.

189-199. », Abstracta Iranica [En ligne], Volume 28 | 2007, document 118, mis en ligne le 18 septembre 2007, consulté le 25 septembre 2020. URL : http://journals.openedition.org/abstractairanica/16442 ; DOI : https://doi.org/10.4000/abstractairanica.16442

Ce document a été généré automatiquement le 25 septembre 2020.

Tous droits réservés 


\section{«Un écho aux pratiques cultuelles zoroastriennes en Dt 4-5 ». Trans., 29, 2005, pp. 189-199.}

\section{Astrid Nunn}

1 Les Juifs se sont-ils intéressés à la religion des Perses? Les apparences suggèrent une réponse négative. Mais est-ce bien vrai ? Une relecture du texte tardif $D t 4$, où le thème du feu est présenté de manière unique dans la Bible, amène l'A. à penser que le «feu » évoqué est celui de la religion mazdéenne.

INDEX

Thèmes : 3.2.2. Pré-Achéménides et Achéménides

\section{AUTEURS}

ASTRID NUNN

Université de Munich 